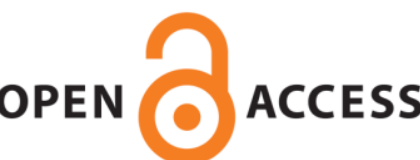

UWS Academic Portal

\title{
Constructing the 'immigrant'
}

Pautz, Hartwig

Published in:

German Politics

DOI:

10.1080/09644008.2017.1312351

E-pub ahead of print: 15/05/2017

\section{Document Version}

Peer reviewed version

Link to publication on the UWS Academic Portal

Citation for published version (APA):

Pautz, H. (2017). Constructing the 'immigrant': Germany's radical left in the 'refugee crisis'. German Politics. https://doi.org/10.1080/09644008.2017.1312351

\section{General rights}

Copyright and moral rights for the publications made accessible in the UWS Academic Portal are retained by the authors and/or other copyright owners and it is a condition of accessing publications that users recognise and abide by the legal requirements associated with these rights.

\section{Take down policy}

If you believe that this document breaches copyright please contact pure@uws.ac.uk providing details, and we will remove access to the work immediately and investigate your claim. 
Dr Hartwig Pautz

Lecturer in Social Sciences

University of the West of Scotland

School of Media, Culture and Society

Elles Building East L204

Paisley PA1 2BE

United Kingdom

Email: hartwig.pautz@uws.ac.uk

Phone: (0044) 01418483770

\section{Biographical note}

Hartwig Pautz is Lecturer in Social Sciences at the University of the West of Scotland. His research interests lie on the relationship between politics, policy and expertise; on e-democracy and participation; and on debates about national and cultural identity in the German context. He has also recently worked closely with Oxfam Scotland on a research project on the theme of 'decent work'. Hartwig is co-convenor of the German Politics Specialist Group of the Political Studies Association (UK).

\section{Constructing the 'immigrant': Germany's radical left in the 'refugee crisis':}

The article scrutinises how Germany's non-political party radical left has discussed immigration and 'cultural' or 'national' identity in the context of past and current immigration into Germany, with a focus on the refugee crisis of 2015. Three types of radical left discourse are identified. First, some in this radical left have come to regard immigrants, in particular refugees, as an 'ersatz proletariat' and therefore as potential revolutionary instrument for their own project. Second, some agree that revolutionary change is necessary but subordinate their principles to practical support of immigrants and refugees in the here and now. Third, given the improbability of communist revolution and the crisis of 'Western modernity', some in the radical left have called for the defence of 'the West' and to help immigrants assimilate into Western civilisation to emancipate themselves from their oppressive communitarian identity.

The article makes a timely contribution to the knowledge about contemporary radical left politics in Germany and shows the fractured nature of Germany's non-political party radical left in the context of the refugee crisis. It also investigates the impact of 'crisis' as an 'open moment' and 'catalyst' on the radical left's discourse-as-practice.

Keywords: refugee crisis, radical left, immigration, identity, Anti-Germans, migration, crisis

Word count: 7972

\section{Introduction}

Not only since the extraordinary rise in the number of people seeking refuge in Germany from poverty and war - beginning in 2013 with an increase to 127.023 refugees $^{1}$ and growing to a peak of 1.1 million in $2015^{2}$ - have immigration and related topics such as asylum policy, integration policy, and national or cultural identity been controversial in Germany. However, it is the so-called refugee crisis which, since 2013, has left a lasting mark on German politics, and politicised immigration and related topics to a degree not seen since the surge in refugee numbers during the Balkan wars in the early 1990s.

The refugee crisis brought to the fore, in an intense and often acrimonious public debate, difficult 
questions on how much immigration and of what kind is possible and desirable, about the impact of immigration on economy, security, welfare state, nation and identity, and about what kind of policies could be adopted to 'manage' immigration. There are too many voices and discursive strands to be even listed here. Therefore, the article shines a light on only one specific set of contributors to this debate, one which has been peripheral in this debate and has attracted no attention from academic scholars: Germany's non-political party radical left.

What are, given this focus, the objectives of this article? The article presents an analysis of the discourse of Germany's non-political party radical left with a temporal focus on the moment when it was confronted with the refugee crisis whilst entering its third decade of continuous decline - if waning membership, increasingly 'reactive activism', and diminishing public visibility are indicators for a downward trajectory. ${ }^{3}$ This analysis is motivated by the understanding of crises, generally, as 'open moments' ${ }^{4}$ and as catalysts for change. Therefore, the theoretical expectation underpinning this analysis is that the refugee crisis has tested the non-political party radical left's ways of thinking, speaking and acting on topics of high significance to its own political identity - capitalism, racism, imperialism, national or cultural identity, and the liberal (nation) state and its sovereignty as expressed in border, citizenship and identity regimes. ${ }^{5}$ Based on this expectation and narrowing the analytical focus, the article asks whether and, if so, how immigration generally and immigration in the form of the refugee crisis of 2015 specifically have impacted on the German non-political party radical left's discourse on immigration and identity. This analysis is guided by an understanding of 'discourse-associal-practice', discussed later.

These objectives also address a gap in knowledge. The article analyses a set of political actors not usually awarded much interest by the academic community, in particular at a time when much attention is on political mobilisations on the far-right. However, to fully understand the impact of the current politic isation of immigration and identity on public debate and policy, the political spectrum ought to be analysed in its entirety - and the article does its share to address this necessity.

The article also wishes to encourage further research in this area. While it discusses only Germany's non-political party radical left, similar actors can be found throughout Europe. These are often connected in transnational networks. The article therefore invites other researchers to direct attention to the non-political party radical left elsewhere and to think about comparative research.

Description and analysis presented here are based on published texts only. The material consists of radical left groups' websites, blog posts, flyers, magazines - i.e. sources published in the non-political party radical left's 'counter public'. ${ }^{6}$ Most of the material is in German - the original quotations can be found as supplementary material online. The search for relevant documents was led by the prior identification of non-party political radical left actors. This process was guided by the public selfidentification of such actors and, more importantly, by the application of the definition, discussed 
below, of what is meant by 'non-political party radical left'. Texts were identified as relevant via key terms such as the German-language equivalents of 'refugee crisis', 'refugee', or 'immigrant' and via whole phrases signalling the discussion of national borders, national or cultural identity, the role of the state in immigration regulation, or the political objectives of radical left groups in relation to the refugee crisis. In line with the temporal focus of the article, most texts stem from the period between 2013 and 2016, but some texts date back to the 1990s and 2000s to explain the genesis of particular discourses. The text corpus was read and re-read closely with the aim of identifying patterns which would lead to the establishment of discourse types.

No primary data was generated for this paper. A survey would have been impossible to distribute to relevant respondents, while interviewees would have been difficult to identify and contact given, for example, the fluid nature of 'memberships' in relevant groups, the reluctance of members of the radical left to engage with outsider researchers, and given that texts are often published under pseudonyms or anonymously. However, for future research undertakings interviews would add to the understanding of how and why different actors in the non-political party radical left conceptualise issues around migration and act upon these. The article does not consider written sources such as grey literature which is often only available for short periods in the physical locations of the counter public, i.e. in the many 'Infoläden' or alternative libraries, cafés, independent youth centres or squatted houses where the radical left lives, organises, meets and discusses. Furthermore, minutes from meetings and other types of internal documents were not available for this research and are unlikely to be in the public domain soon, given their nature and the time-lag between production of such documents and their (often unlikely) appearance in publicly accessible archives.

The texts chosen were analysed as discourse in the sense of 'social practice. This implies a dialectical relationship between a particular discursive event and all the diverse elements of the situation(s), institutions(s), and the social structures(s) which frame it'. ${ }^{7}$ Such a dialectical relationship means that discourse is 'socially constitutive as well as socially shaped: it constitutes situations, objects of knowledge, and the social identities of and relationships between people and groups of people' ${ }^{8}$ In the context of this article, such an understanding of discourse underlines that the refugee crisis can be expected to have influenced the discourse of the non-political party radical left on immigration and identity. Similarly, the non-political party radical left's 'own' internal crisis can be expected to have influenced its relationships with other social actors, including refugees and immigrants. This view of discourse, taken from Critical Discourse Analysis (CDA), chimes with the understanding of 'crisis' as an open moment and as a catalyst for change, including a change in discourse.

Approaching the matter through CDA also underlines that the constitution of 'the refugee' or 'the immigrant' is likely to differ as it depends on the political identities and associated objectives of the 'discourse producers'. These differences can be significant for object of the discourse. After all, the 
constitution of an immigrant as a 'threat to security', 'revolutionary agent' or as an 'enrichment of society' can have severe consequences for the immigrant, depending e.g. on their relationship to the discourse producer and their power and interests: 'Thus, discursive practices may have major ideological effects, [..] they can help to produce and reproduce unequal power relations [...] through the ways they represent things and position people'. 9 The analysis of such discursive practices therefore can demonstrate how discourse can generate or deepen inequalities or injustices and influence hierarchies. It can thus redeem the emancipatory promise ${ }^{10}$ which sets CDA apart from other approaches to discourse analysis and lends it its particular appeal for those who understand the social sciences as tasked with producing 'critical knowledge' and not just description and explanation. ${ }^{11}$

In short, the analysis presented here is informed by CDA's understanding of discourse-as-socialpractice because it allows an appreciation of the importance of discourse as constitutive of the social world and its power asymmetries, and because it allows taking into account the impact of crisis on discourse. As CDA is not a 'method' but rather a state of mind to critically understand how language and social structures are interrelated ${ }^{12}$, the methods of identification and analysis of the text corpus described earlier were chosen to match the analytical challenge of identifying different 'discourse types'. ${ }^{13}$

The remainder of the article develops as follows: After a definition of 'non-political party radical left', the three discourse types will be analysed, supported by an as-rich-as-possible reproduction of texts translated from German into English by the author. A conclusion will round off the article.

\section{What and who is the 'non-political party radical left'? A definition.}

There is disagreement when it comes to the analytical terminology for political organisations and ideologies beyond what could be considered the political mainstream. Are adjectives such as 'radical', 'extreme', 'extremist' or 'far left/right' appropriate when we talk about political forces and ideas outwith this supposed mainstream? Certainly, these terms, their usage and their meaning are dependent on context. They can also, it seems, be normatively laden and politic ised. In West Germany, the domestic intelligence service used the term 'radical' until the mid-1970s to describe opponents of German parliamentary democracy both from the left and the right. Today Germany's intelligence service uses the noun 'extremism' to describe those wishing to abolish the current political order, while those voicing 'only' fundamental criticism of this order are labelled 'radical' ${ }^{14}$ regardless of their right-wing or left-wing provenance.

Within the academic debate on the usefulness of this terminology, some propose that the term 'extremism' can be applied to both left and right political thought. However, the proponents of this 'extremism theory' 15 are criticised for reducing the difference between Nazism and communism to 
mere nuance and for denouncing any criticism of capitalism and liberal democracy as 'dangerous'.16 Others use terms such as 'radicalism' and 'extremism' almost interchangeably. For example, Max Kaase applies the term 'radical' to explain 'left extremism' to denote a radical-democratic, egalitarian understanding of politics. ${ }^{17}$ Following similar reasoning but making a firm choice of terminology, Willibald Holzer proposes restricting usage of the term 'radical' to those political forces rooted in Enlightenment thinking ${ }^{18}$, thus excluding the far right.

Those focussing on the study of political parties seem to prefer the use of 'radical' over 'extreme' when discussing parties on the left part of the political spectrum. However, it is contested which characteristics - origin, policy, or ideology - should be used to classify a political party as belonging to the 'radical left'. There is also debate over which sub-classifications are meaningful under the broader category of 'radical left party'. ${ }^{19}$ If policy and ideology are chosen as classificatory characteristics, then radical left parties are defined as those which reject the 'socio-economic structure of contemporary capitalism and its values and practices. [...] They advocate alternative economic and power structures involving a major redistribution of resources' ${ }^{20}$ However, radical left parties often pursue a 'situational' radicalism that is falling short of the full anti-capitalism which non-political party actors endorse. Nonetheless, they still articulate issues that are radical in the party's national situation. 21

The literature on political thought and on left political parties, briefly discussed above, has informed the definition of 'non-political party radical left' applied in this article. First, the term 'radical' is preferred over that of 'extreme' as 'radical'. With its etymological origin in the Latin for 'relating to the roots', it aptly emphasises the stark and revolutionary extent of the departure from the status quo which underlies ideas and action of those in the 'radical left'. ${ }^{22}$ Second, while the discussion presented here focusses exclusively on non-political party actors, they share the defining ideological objectives - but not the means to obtain them - with radical left parties. That means that for the purposes of this article - i.e. the identification of actors and relevant texts for analysis - the "non-political party radical left' was defined as follows: all non-political party forces that seek to fundamentally change essential elements of the current capitalist and liberal-parliamentarian democratic system towards a radical democracy and egalitarian societal relations which extend into all spheres of life, under guidance of the broad tradition of socialism, anarchism or Marxism. A warning is in place: a definition such as this cangive the false impression that an empirical phenomenon is clear-cut and easily distinguishable from the next. In the context of this article, the emphasis on a 'radical left' located exclusively outside the electoral arena could suggest that there are firm boundaries between radical left actors outside electoral politics and those organised in party-political form. That such firm boundaries do not always and necessarily exist is demonstrated by political groups within the now long 'institutionalised' 23 German party 'Die Linke'. Associations such as the 'Kommunistische Platform' and the 
'Antikapitalistische Linke' have benefitted from Die Linke's organisational and financial strengths while pursuing an agenda or using methods sometimes in conflict with the party's activities and policies moving within the parameters of parliamentarian democracy. While the links between nonpolitical party radical left and far-left parties - including those on the extreme and radical left ${ }^{24}-$ would be relevant to study also with regards to the reciprocal influence on discourses on immigration and identity, this article is limited to those actors on the radical left with no stake in electoral politics and therefore unfettered by such politics with regards to political instruments, and uncompromised in their values and objectives by party organisations or the requirements of parliamentary democracy. Lastly, the definition applied in this article could suggest that what is called 'non-political party radical left' is a united bloc. This is certainly not the case with regards to the how the radical left speaks of the means for building a different society - some groups may favour militancy and others insist on non-violent instruments - and vis-à-vis the very different expressions of the radical left's 'prefigurative politics'25.

This diversity is reflected in the cosmos of non-political party radical left organisations identified for this article. This cosmos is not static. Organisations often emerge when a political matter arises, and disappear again, or morph into a different shape when the situation allows or necessitates. Factions within the radical left emerge along often intense ideational fault lines and can create new organisational expressions. The German non-political party radical left is concentrated particularly in Berlin and Hamburg and in university towns. There seems to be a trend to further such concentration confirming, perhaps, the crisis of the radical left as it is also conveyed in the domestic intelligence service's estimates of decreasing membership of the 'extreme left' - down to 26.700 from 31.800 in 2011. However, in 2015 'militancy' increased, according to the intelligence service. ${ }^{26}$ In this article, the texts produced by only a relatively small number of organisations and more fluid ideational groups were taken into account. Among these were the immigration policy focussed network 'Kein Mensch ist Illegal' (No-one is Illegal, founded 1997), the refugee-led 'Caravan for the Rights of Refugees' (founded 1998), a network of refugee activists called 'The Voice' (founded 1994), and the solidarity campaign 'Lampedusa in Hamburg' (founded 2013). Beyond those in the radical left exclusively focussed on refugees and asylum seekers, organisations such as 'Für eine linke Strömung' (For a Left Current, founded 1991) and its successor, the 'Interventionistische Linke' (founded 2005/2015), the autonomist-communist association 'Ums Ganze', (For the Whole, founded 2006), and a number of local anti-fascist groups are included in the analysis. Locally organised anti-gentrification movements - a significant topic for the radical left and often one which connects with the political mainstream such as the Hamburg-based 'Recht auf Stadt' (Right to the City, founded 2009) are also discussed. A last example of a formal organisation is the 'Kommunistischer Aufbau' (Communist Platform, founded 2014) which espouses Leninist organisational principles. As the radical left does not always 
appear in the form of organisations but also loose associations, the central publication of the 'AntiGermans', the 'Bahamas' magazine (founded 1992), was analysed, too, for its contributions to the discourse.

To conclude, while there is demonstrable diversity within the non-political party radical left, and while there are overlaps between actors such as the ones in the focus of the article and political parties, the proposed definition of 'radical left' based on distinct ideology and long-term objectives to be achieved through non-parliamentarian means clearly demarcates a particular set of actors. In the remainder of the article, the shorthand term 'radical left' will be used to refer to the 'non-political party radical left'.

\section{Immigration, migrants and identity: three discourse types}

The remainder of the article seeks to address the research objectives outlined earlier. Focus is on the years between 2013 and 2016 as the refugee crisis in combination with terror attacks and the upsurge of far-right politics in its parliamentary and extra-parliamentary forms in Germany can be considered a qualitatively unique challenge (not only) to the country's radical left. However, some recourse to the 1990s and 2000s will be made to explain the genesis of particular discourses.

\section{Discourse A: Instrumentalisation of refugees as 'ersatz proletariat'}

The failure of 'actually existing socialism' in East Germany and the unification of West and East Germany in 1990 led to much soul-searching in Germany's radical left. With communism and socialism discredited and the working class never further from assuming its historical role as revolutionary subject, intellectual circles and activists of the anti-racist, antiimperialist/internationa list, anti-capitalist and anti-fascist radical left started to debate their theoretical foundations and their praxis. Among the most pressing problems was the search for an 'ersatz proletariat', i.e. a historical subject in lieu of the working class.

The analysis of publicly available texts shows that the refugee crisis was seen by some in the radical left as a window of opportunity to deal a blow to European capitalism, including the European Union itself, the Dublin II system and the Frontex border agency. In 2013, when refugee numbers had already been rising consistently, an author in the weekly left paper Jungle World celebrated that 'these refugee struggles are transnational and cannot be controlled through any increasingly authoritarian migration checks'. The paper continued that

the criticism of the European camp and deportation system is necessarily a criticism of globalised actually existing capitalism. The radical left has the unique opportunity to re-assert its project of universal liberation in this [refugee, the author] struggle ${ }^{2}{ }^{27}$ 
The migrants themselves therefore are both instrument and subject in this struggle, led by a vanguard that had been waiting for the next opportunity to overturn capitalism. However, refugees should not count on the unconditional solidarity of the radical left, or on practical support to find a safe place in Germany. In February 2015, the Radikale Linke Berlin, a diverse organisation based in the anti-fascist movement and founded in $2014^{28}$, indicated it would not join efforts to make life easier for refugees arriving in Germany or support refugees if this meant addressing the state with demands:

Even if we want to participate in refugee protests and even if we support the various struggles and demands of those fleeing, as a group we will not send pleas, petitions or requests to the state. To call upon this system and this state is wrong. This state and this system are not addressees for pleas and calls. This state and this system must be rejected. ii $^{\text {. }}$

Rather than supporting all refugees, the Radikale Linke wants to identify those among the refugees who want to join their struggle for a different society: in order to 'end the madness of capitalism' the group would 'support the autonomous protests of the refugees and join in their struggle for a life in dignity and equality. We will support these struggles to the best of our abilities. [...]. We will look for those who organise themselves and want to fight in order to establish another society' ${ }^{\text {iii. }}{ }^{29}$ Other voices from the autonomous and communist movement demanded, in December 2015, that the radical left should form a united front with refugees to combat the supposedly shared enemies. The alliance For the Whole called the flight of people from their countries of origin an 'opportunity for a shared attempt at changing the present conditions'iv, and declared that the general fight of the radical left against Germany as an 'authoritarian competition state' should proceed alongside 'attempts to tear holes into the border regime of selection and seclusion'30 in an effort that would result in more immigration into Germany of people with revolutionary potential.

Voices from the non-party Communist-Leninist left demonstrated an even more instrumental view on the historical role of the refugee and immigrant in Germany and Europe. Overlooking what immigrants may wish for themselves or what kind of cultural or political identity or class background they may arrive with in Europe, the Communist Platform wrote that 'the refugees and migrants in Germany are part of the working class. The refugee question, the strategy of the bourgeoisie vis-à-vis the refugees and the political resistance fight of the refugees and their supporters are therefore special forms of class war of the proletariat against the bourgeoisie'v. ${ }^{31}$

This discourse type - of the 'ersatz proletariat' - existed already prior to the refugee crisis. For example, the organisers of an anti-racist border camp in 2002 wrote in their rationalisation of the 
event that 'our intention is to link the tactical demand for an improvement of the living conditions of refugees with a radical criticism of society' ${ }^{32}$. Such views were frequent even among groups which actively campaigned against legal restrictions to the free movement of refugees and asylum seekers in place at the time. In Germany, the so-called 'Residenzpflicht' legislation, which severely limited asylum seekers' geographical mobility, was a strong campaign focus for the left in the late 1990s and galvanised action against the government. Groups which sought to bring German activists together with refugees - in order to move beyond the clientelistic model of 'helping refugees' - such as The Voice or The Caravan for the Rights of Refugees wanted to contribute to concrete policy change but usually connected this with radical demands and criticism. For example, The Voice, in 2007, denounced the German state by equating the Residenzpflicht to the 'Israeli way of segregation and limitation of freedom of movement for Palestinians'vi.33 Furthermore, the group analysed the Residenzpflicht as leading to

the isolation and the social exclusion of refugees. [...] The Residenzpflicht negates any thought about integration. It is a continuation of the racist and fascist ideology which serves the interests of its adherents by excluding and criminalising certain social groups and presents them as 'alien bodies' and as in need of getting rid of ${ }^{34}$. viii

While this proclamation took its departure from the criticism of concrete policy with the objective of improving refugees' life in Germany, it also very clearly is about the radical left's overall objective of radically changing 'the system', denounced as 'fascist' and 'racist'. Moreover, groups such as the Voice or The Caravan have often discussed whether they should declare solidarity with refugees and the refugee movement when these do not share the aim of revolutionary transformation in Germany. In sum, this discourse type constitutes the immigrant and in particular the refugee as a revolutionary catalyst or instrument, conceding only limited autonomy to the immigrant or refugee as it constitutes them as subordinated to the autochthonous radical vanguard and its objectives. Questions of cultural or national identity are rarely touched upon in this discourse type as the immigrant is seen in terms of class. The immigrant or refugee is not constituted as an individual to be assisted with 'integration' in Germany if this implies negotiating and accommodation with 'the state'. Arguably, the refugee crisis fuelled this discourse type as it gave a certain faction of the radical left a new rallying point for their political project under the impression of a large, albeit temporary, spike in immigration.

\section{Discourse B: No borders, no nations...but: pragmatic help for refugees and migrants}

A second discourse type puts the emphasis, first, on the responsibility of those in Germany's radical left to practically help refugees and immigrants to come to Germany and to stay there and, second, 
on the necessity to make vocal demands, in effective coalition with non-radical civil society actors, on the state to change policies considered discriminatory or as violations of human rights. These two aspects have created tensions and contradictions vis-à-vis the fundamental radical left principles endorsed by those actors understood here, in this article, to be producers of this second discourse type.

This discourse type, again, existed before the refugee crisis. It was specifically the harmonisation of EU migration policies in the mid and late 1990s - coming to a first conclusive step with the 1999 Treaty of Amsterdam - upon which resistance against what was perceived to be a highly restrictive border and immigration regime formed. Within the German context, the development of a coordinative network by existing and diverse anti-racist refugee and migrant solidarity organisations called 'Kein Mensch ist illegal' (No-one is Illegal, KMII) was the organisational expression of this resistance. Founded in 1997 at the 'documenta X' art exhibition, KMII was inspired by the French Sans Papiers ${ }^{35}$, associated with the international No Borders network, and brought together local groups from a broad range of political persuasions and backgrounds. In its 1997 manifesto, KMII formulated a central demand: 'everybody has the right to decide where he wants to live and how. We reject borders which hinder people to decide where they live' viii ${ }^{36}$ While assuming a radical left position which denied the legitimacy of a central characteristic of the sovereign nation state, KMII and its constituent organisations invested most energy in day-to-day praxis to support immigrants and refugees survive in illegality or to help them 'become legal'. These activities included giving advice on how to help migrants over the heavily guarded Schengen borders into Germany and the organisation of accommodation, school attendance and medical help for illegalised immigrants. ${ }^{37}$ In addition, groups organised in the KMII network also organised direct action to stop deportations ${ }^{38}$ and took part in public campaigns to advocate for policy change. Even though much of KMII's public political praxis was designed to draw in people from non-radical backgrounds ${ }^{39}$, in 1998 the domestic intelligence service categorised KMII as a 'left wing extremist' organisation ${ }^{40}$ - a judgement not repeated since.

While the KMII network wanted to be praxis-oriented, it rejected the sovereign state and its legitimacy to decide who can live within its borders. Furthermore, organisations in the KMII network made no secret of their hopes that global migration would spell an end to the nation state. Guided by such radical left principles, under the impression of growing refugee numbers arriving on the Italian island of Lampedusa in 2008, and fifteen years after much-criticised restrictions to German asylum law came into force ${ }^{41}$, a group associated with KMII stated that they were fighting 'for a global right to migration - for freedom of movement and de*fencing the nations' ${ }^{\prime}$. . But the tension between this radical demand and the rejection of capitalism as the main cause of mass migration to 'Fortress Europe' on the one hand, and the 'pragmatic' demand, led by the wish to help refugees stay in 
Germany, that the German government revise legislation on the other hand, is palpable in this publication and elsewhere. ${ }^{42}$ Such tension also appeared in discussions about the 'reformist' demand to 'legalise' those without papers, seen by a minority as undermining the radical demand for the abolition of borders. ${ }^{43}$

As a country-wide coordinating network, KMII is today history. However, 'No-one is illegal' survives as a frequently-used 'brand' by local groups committed to helping migrants live in Germany. This pragmatic discourse, sometimes coupled with radical but always subordinated principles, has been effective in more recent years. One example is 'Lampedusa in Hamburg'. This became the name for a group of about 300 people who had escaped from Libya and arrived, via the Italian island of Lampedusa, in Hamburg in 2013. Threatened with their deportation to Italy according, the group organise public protests and petitions and occupied buildings with the aim to obtain the right to stay in Germany. While their campaign received support from a range of civil society actors, including the churches, support from the radical left was important and came from groups such as 'The Caravan for the Rights of Refugees', members of 'ATESH - For a Social-revolutionary Perspective!', the local anti-fascist and anti-racist movement, ${ }^{44}$ KMII Hamburg and an anti-gentrification alliance called 'Right to the City' which, in 2015, demonstrated under the slogan 'Right to the City - never mind the papers'. ${ }^{45}$ Similarly, in February 2016, The Caravan for the Rights of Refugees organised a protest in Munich for the right of refugees to stay in Germany while branding German legislation as 'racist'. Simultaneously, it offered practical help to immigrants in cooperation with a diversity of civil society actors. 46

These and further examples demonstrate a discourse-as-social-practice which subordinates the radical left critique of the current political order to organising practical help to stay in Germany and to advocating policy change even if this means working with individuals and groups from elsewhere in civil society and accepting the state as an addressee for claims. However, those actors who discursively constitute the immigrant or refugee as an individual in need of support whilst emphasising that they are an autonomous subject find themselves in difficult waters as their radical left principles are in open contradiction to their day-to-day praxis. On the other hand, strict adherence to these principles would limit the ability to advocate for policy change or to negotiate with public officials with the aim to support, for example, individual refugees. The refugee crisis has led to a sharpening of these tensions whilst at the same time demonstrating the need for pragmatic help and continued policy activism towards a more open immigration system.

Discourse C: Support immigrants to succeed in bourgeois society - because that's what they want In the early 1990s, a small group of dissenters split from the West German non-parliamentary communist left. This association became known as the 'anti-nationals' or as the 'Anti-Deutsche', the 
Anti-Germans, ${ }^{47}$ because it was German unification, the subsequent flourishing of national sentiment, and the waves of racist pogroms which gave some on the radical left an impetus to rethink the radical left project. The specific fear was that a united Germany would - again - pose a threat to 'Westem modernity'. In conjunction with a forceful criticism of the anti-imperialism/anti-colonialism and antiZionism, anti-fascism, anti-racism and anti-capitalism of the 'traditional' German radical left, the Anti-Germans argued that the radical left should more critically discuss the themes of 'nation' and 'identity'. Some argue that the Anti-Germans' critique was responsible for a 'structural reconfiguration' of the radical left. ${ }^{48}$ A later, but equally important juncture for the Anti-Germans were the terror attacks of ' $9 / 11$ '. Since then, the Anti-Germans, most vocally in their magazine 'Bahamas', have argued that Islam's anti-Western ideology chimed dangerously well with many in Germany's left. Whilst maintaining that a communist revolution was desirable and should be actively sought, given its unlikely advent in the near future and given the threats posed both by Islam and the rise of 'identity politics' and nationalism, the Anti-Germans urged the radical left to defend the achievements of Western modernity - including the rule of law, civil liberties, and individual freedom $^{49}$ - rather than fighting the fights of the 1960s and 1970s.

In combination with their explicit support of Israel and their denunciation of anti-Semitism and antiAmericanism elsewhere in the radical left, this stance has marginalised the Anti-Germans in the radical left. Not few consider the Anti-Germans to have their rightful place among reactionary forces and accuse them of 'Islamophobia'50 and 'racism'51 or call them a 'plague'. ${ }^{52}$ Nonetheless, the AntiGermans consider themselves as a 'corrective' to the German radical left as one of their mottoes 'Against the left consensus!' $\times 53$ demonstrates, and continue to advocate the principles of communist society using Marx, Freudian psychology and Critical Theory as their intellectual foundations.

How do the Anti-Germans discursively constitute the immigrant? During the refugee crisis, AntiGermans criticised that 'asylum seekers have taken over the function, for the radical left, which once the proletariat had. Based on their origin they are seen as allies who will help them to get the revolutionary cart unstuck from the mud'xi. ${ }^{54}$ However, as Anti-Germans argued, the radical left should realise that migrants arriving in Europe want nothing but paid employment and a slice of Western life. They also may often have used their 'elbows', as illegally entering 'Fortress Europe' requires exactly those survival skills which are needed for successful competition on Europe's labour markets. ${ }^{55}$ The Anti-Germans also mocked what they saw as the disappointment among the radical left when 'the new arrivals do not want to play the noble savage but rather, as quickly as possible, want to enjoy the advantages of western lifestyles for which the European autochthonous today have nothing but contempt'. 56

The Anti-Germans implored the radical left to help refugees integrate into 'the West'. ${ }^{57}$ In order to do so, the Anti-Germans called upon the radical left to stop projecting their own desires for a 'cultural 
identity', unadultered by Western civilisation, on refugees and other immigrants. This would only lock them into their supposed identity communities and stop any attempt to emancipate as individual. Already in 2005, authors in the Bahamas argued that rather than 'representing people and their supposedly threatened identities' xiiis8 the radical left should reject the anti-Western notion of 'cultural authenticity' and embrace immigrants as individuals. This demand was repeated during the refugee crisis, when Anti-Deutsche criticised those 'among the friends of the welcome culture [the term popularly used to describe Germany's initial response to the 'refugee crisis', the author] for whom everything which is not sheer enthusiasm for alien cultures passes as racism' ${ }^{x i i 59}$.

Among the Anti-Germans, this stance on 'identity' and 'culture' gained prominence with the refugee crisis. But long before the crisis, the Anti-Germans had warned that more and more anti-Western communities were emerging around Islam in Europe. For the Anti-Germans, these communities are 'identity hells' from which people should be rescued by offering them opportunities to assimilate into what they consider to be the most advanced human project, 'the West'. ${ }^{60}$ In 2005, the Bahamas magazine referred to a

café owner of Turkish descent [...] who in 2003 remarked to the Tagesspiegel newspaper that he had not moved to Germany to find a mosque at every street corner like in Turkey. Those who really need mosques should have stayed in Turkey. But those migrants from Turkey who refuse to bow to the imposition to be a 'Muslim' qua origin, have no voice. These people, who speak German and Turkish but certainly not 'kanak sprak' [a term popularised by author Feridun Zaimoğlu to positively describe the sociolect of TurkishGermans, the author], those who claim the right for themselves to be normal [...] are under increased surveillance: It could be that they are on the side of the adulators of western civilisation ${ }^{\mathrm{xvii}}{ }^{61}$

However, the Anti-Germans already then were full of despair about those in the autochthonous radical left who were unwilling to help gain 'normal people' voice, an act which the Anti-Germans understood as a 'civilising effort' 62 .

In short, this discourse type constitutes immigrants and refugees as individuals coming to Europe with the desire to adopt 'western attitudes and behaviours' ${ }^{\text {xviii63 }}$ and, in the case of immigrants from predominantly Muslim countries, to become individuals safe from the 'impositions of Islam' xvi64. It calls upon the radical left to help these people 65 to join 'the West' as a 'project for the civilisation of the individual'xix 66 and not to abuse the immigrant as a political instrument. However, in particular already existing Muslim immigrant communities are represented as hostile to 'the West', and newlyarriving refugees as in danger of being absorbed into these communities. For the Anti-Germans, the 
refugee crisis has underlined some of the concerns which led to the creating of the Anti-Germans in the first place - the worry about the radical left's disenchantment with Western modernity and the supposed threat of Islam to this modernity. The resulting demand to understand the refugee as someone to be helped towards assimilation distanced the Anti-Germans even further from others in the radical left, as did the Anti-Germans.

\section{Summary and conclusion}

The article presented an analysis of the discourse of Germany's non-political party radical left with a focus on the moment when it was confronted with the refugee crisis whilst entering its third decade of continuous decline. This analysis was motivated by the understanding of crises as 'open moments' and catalysts for change. Therefore, the theoretical expectation underpinning this article was that the refugee crisis tested the radical left's ways of thinking, speaking and acting on topics of high significance to its own political identity. Did then immigration generally, and immigration in the form of the refugee crisis of 2015 specifically, impact on the German radical left's discourse on immigration and identity?

The article presented evidence for the existence of three different discourse types within Germany's radical left on these themes without assessing the strength of one discourse type over the other future research could search for such tendencies within the radical left. Within the first type, immigrants, in particular refugees, were socially constituted as a much-needed 'ersatz proletariat' which can re-energise the radical left project. Faced with the refugee crisis, those producing this discourse constituted refugees as worthy of support only when they side with the radical left, thus confining the refugee to a subordinated position of power vis-à-vis the radical left. A second discourse type constituted immigrants as in need of support to stay in Germany and obliged the radical left to organise solidarity in the form of pragmatic help and political advocacy for and, crucially, with immigrants. In praxis, this has allowed immigrants to develop 'voice' and agency. Radical left stances on immigration, the state and borders were subordinated - albeit sometimes uneasily - to support and advocacy. A third discourse type, that of the Anti-Germans, was almost exclusively focussed on Muslim immigrants and constituted them in two main ways. On the one hand, the Anti-Germans saw their desirable assimilation into 'the West' under threat by an anti-imperialist, anti-racist and anti-capitalist radical left that feels nothing but contempt for Western modernity and therefore wishes to deny immigrants access to it. On the other hand, refugees and immigrants with a Muslim cultural identity, protected by a radical left which has come to project its own unrealisable desire for 'cultural authenticity' onto refugees and immigrants, are constituted as a threat to 'the West'.

Each of these discourses constitutes 'the refugee' or 'the immigrant' differently depending on the political identities and associated objectives within the radical left. While the 'role of discourse in the 
(re)production and challenge of dominance'67 was not central to the analysis presented here, the consequences of the different discursive representations of immigrants were flagged up where possible. The aim was to show how some political actors, subscribed to a politics opposed to oppression and exploitation, have themselves discursively reproduced strict social hierarchies and have made political and practical support conditional. Further analysis could try understand whether the different discourse types identified have had 'real life consequences' on immigrants, including the refugees arriving in Germany during the refugee crisis.

What could the consequences of the refugee crisis be on the radical left, generally speaking? It seems that the refugee crisis, earlier referred to as an 'open moment' and as a potential catalyst for change, has contributed to even more fragmentation and turbulence in the radical left's ways of thinking, speaking and acting. In that sense, the crisis has been a challenge for a radical left already in decline and increasingly less able to organise in other than defensive and reactive ways.

\footnotetext{
${ }^{1}$ Bundesamt für Migration und Flüchtlinge, BAMF Migrationsbericht im Auftrag der Bundesregierung, 2013, available from $\quad$ http://www.bamf.de/SharedDocs/Anlagen/DE/Publikationen/Migrationsberichte/migrationsbericht2013.pdf? blob=publicationFile, (accessed 17/09/2016).

2 Die Welt, '1-1-Millionen Flüchtlinge kamen 2015 nach Deutschland', Die Welt, 6 January 2015, available from http://www.welt.de/politik/deutschland/article150678614/1-1-Millionen-Fluechtlinge-kamen-2015-nach-

Deutschland.html, (accessed 15 March 2016); Statista, 'Asylanträge in Deutschland seit 1995', available from http://de.statista.com/statistik/daten/studie/76095/umfrage/asylantraege-insgesamt-in-deutschland-s eit-1995, (accessed 13/09/2016).
}

3 Bundesministerium des Innern, Bundesverfassungsschutzbericht 2015, available from https://www.verfassungsschutz.de/de/oeffentlichkeitsarbeit/publikationen/verfassungsschutzberichte, (accessed 20/11/2016), p. 107.

${ }^{4}$ B. Laffan, 'Europe's union in crisis: tested and contested', West European Politics 39/5 (2016), pp. 915-932, p. 917.

${ }^{5}$ For a comprehensive list of political is sues of important is sues for the radical left see RaulGomez, Laura Morales and Luis Ramiro, 'Varieties of Radicalism: Examining the Diversity of Radical Left Parties and Voters in Western Europe,' West European Politics, Vol39(2) (2016), pp. 351-379, p. 360.

6 see C. Spehr, 'Entwicklung und Bedeutung der Begriffs „Gegenöffentlichkeit“", available from www.linksnet.de/de/artikel/18209, (accessed 13/09/2016); N. Fraser, 'Rethinking the Public Sphere. A Contribution to the Critique of Actually Existing Democracy', in B. Robbins (ed.) The Phantom Public Sphere (Minneapolis: University of Minnesota Press, 1993), pp 1-32; S. Aranowitz, 'Unions as Counter-Public Spheres', in M. Hill; M. Hill; W. Montag (eds), Masses, Classes and the Public Sphere (London: Verso, 2002).

${ }^{7}$ Norman Fairclough, Jane Mulderigg, Ruth Wodak, 'Critical Discourse Analysis', in T.A. van Dijk (ed.) Discourse Studies: a Multidisciplinary Introduction (London:Sage, 2009), pp.357-379, p. 357.

${ }^{8}$ Ibid., p. 358.

${ }^{9}$ Ibid., p. 357.

${ }^{10}$ Ibid., p. 360.

${ }^{11}$ Ruth Wodak and Michael Meyer, 'Critical Dis course Studies: History, Agenda, Theory and Methodology', in Ruth Wodak and Michael Meyer (ed.) Methods of Critical Discourse Studies (London: Sage, 2016, $3^{\text {rd }}$ edition). Pp. 1-22, p. 7. 
${ }^{12}$ T.A.van Dijk, 'CDA is NOT a method of critical discourse analysis', In: EDISO Debate, May 2013. Online from http://www.edisoportal.org/debate/115-cda-not-method-critical-discourse-analysis, (accessed 1 March 2017).

${ }_{13}^{13}$ Norman Fairclough, 'Discourse and Social Change'(Cambridge : Polity, 1992), p. 5.

${ }^{14}$ Bundesamt für Verfassungsschutz, 'Häufig gestellte Fragen: Was ist der Unterschied zwischen radikal und extremistisch?', website 2016, available from https://www.verfassungsschutz.de/de/service/faq, (accessed 15 March 2016).

${ }^{15}$ Uwe Backes and Eckehard Jesse, 'Politischer Extremismus in der Bundesrepublik Deutschland Vol 1,(Bonn: Propyläen, 1989).

${ }^{16}$ see L. Rensman and C. Kopke, 'Zur politis chen Karriere einer wis senschaftlichen Ideologie', Blätter für deutsche und internationale Politik No 12 (2000); U. Dovermann, 'Streitgespräch zum Thema Linksextremismus zwischen Prof Richard Stoess und Professor Uwe Backes', in U. Dovermann(ed) Linksextremismus in der Bundesrepublik Deutschland (Bonn: Bundeszentrale für politische Bildung, 2000).

${ }^{17}$ Max Kaase, 'Linksextremismus ', in M.G. Schmidt (ed.) Lexikon der Politik Vol 3: Die westlichen Länder (München: C.H. Beck, 1992), p. 232.

${ }^{18}$ W illibald Holzer, 'Rechts extremismus - Konturen, Definitionsmerkmale und Erklärungsmuster', in Dokumentationsarchiv des österreichischen Widerstandes. (ed) Handbuch des österreichischen Rechtsextremismus (Wien: Deuticke, 1994), pp. 12-96.

${ }^{19}$ Gomez et al. 20016, 'Varieties of Radicalis m: Examining the Diversity of Radical Left Parties and Voters in Westem Europe'.

${ }^{20}$ Luke March, 'Radical Left Parties in Europe. Extremism and Democracy', (Abingdon: Routledge, 2011), p.8.

${ }^{21}$ Daniel Keith and Luke March, 'Introduction', in Luke March and Daniel Keith (ed) Europe's Radical Left. From Marginality to the Mainstream? (London: Rowman and Littlefield, 2016), pp. 1-24, p. 7.

${ }^{22}$ Daniel Keith and Luke March, 'Introduction', p. 6.

${ }^{23}$ Dan Hough, Michael Koß and Jonathan Olsen, 'The Left Party in Contemporary German Politics' (Basingstoke : Palgrave Macmillan, 2007), p. 48.

${ }^{24}$ Luke March, 'Contemporary Far Left Parties in Europe: From Marxism to the Mainstream?', in International Policy Analysis (Berlin:Friedrich-Ebert-Stiftung, 2008), available from http://library.fes.de/pdffiles/id/ipa/05818.pdf, (accessed 19/02/2016), p.3.

${ }^{25}$ Carl Boggs, 'Marxism, Prefigurative Communism, and the Problemof Workers' Control', Radical America 6(1977), pp. $99-122$, p 100.

${ }^{26}$ Bundesministeriumdes Innern. (2016) ibid., p. 95; Bundesministeriumdes Innern. (2012) Bundes verfassungsschutzbericht 2011, available from https://www.verfassungsschutz.de/de/oeffentlichkeitsarbeit/publikationen/verfassungsschutzberichte, , accessed 20/11/2016), p. 143.

29 F. Fiedler, 'Antirassismus jetzt!', Jungle World No 49, 5 December 2013, available from http://jungleworld.com/artikel/2013/49/48954.html, (accessed 15 March 2016).

${ }^{28}$ Senat für Inneres Berlin, 'Berliner Verfassungsschutzbericht 2014, available from https://www.berlin.de/sen/inneres/verfassungsschutz/publikationen/verfassungsschutzberichte/verfassung sschu tzbericht_2014.pdf, (accessed2/12/2016),p. 90.

${ }^{29}$ Radikale Linke, 'Wer vom Rassismus spricht', Radikale Linke homepage 25 January 2015, available from https://radikale-linke.net/blog-posts/wer-von-rassismus-spricht, (accessed 13/09/2016).

${ }^{30}$ Ums Ganze, 'all2gethernow: In Bewegung bleiben - Gegen die Abschottung und ihre Fans', 24 December 2015, available from $\underline{h t t p: / / u m s g a n z e . o r g / e i n l a d u n g-r a d i k a l e-l i n k e, ~(a c c e s s e d ~} 15$ March 2016).

${ }^{31}$ Kommunistis cher Aufbau, 'Die „Flüchtlingskris e“ 2015. Imperialistis che Strategien zur Kontrolle der benötigten Arbeitsmigration', Kommunistischer Aufbau 16January 2016, available fromhttp://komaufbau.org/diefluchtling skrise-2015-imperialis tis che-strategien-zur-kontrolle-der-benotigten-arbeitsmigration, (accessed 15 March 2016).

${ }^{32}$ Antiras sistische Gruppe Leipzig, 'Antiracist action and discussion? Camp02', Nadir webpage 2002, available from https://www.nadir.org/nadir/kampagnen/camp02/aufruf2e.htm, (accessed 1 March 2016).

${ }^{33}$ The Voice, 'Einblick in den Kampf gegen die Residenzpflicht', (Förderverein The Voice, Göttingen 2007a), available from http://residenzpflicht-apartheid.net/download/residenzpflicht-reader.pdf, (accessed 14 March 2016), p. 5.

${ }^{34}$ Ibid., p. 6.

${ }^{35}$ Gerda Heck, “'Illegale Einwanderung “. Eine umkämpfte Konstruktion in Deutschland und den USA ' (Münster: Unrast Verlag, 2008), p. 123.

${ }^{36}$ KMII, Kein Mensch ist illegal, Manifest, 1997, available from http://www.kmii-koeln.de/manifest-1997, (accessed 15 March 2016).

${ }^{37}$ KMII Köln, 'Kein Mensch ist illegal', 2000, available from http://www.kmii-koeln.de/kein-mensch-ist-illegal, (accessed 13/05/2016).

${ }^{38}$ Initiative gegen Abschiebehaft Berlin/Kooperative Flüchtlingssolidarität Hannover, 'Abschiebung von Berlin nach Kamerun verhindert!' 19 August 2013, available from http://no-racism.net/article/193, (accessed 15 March 2016); Deportation Class, 'About', 2000, available from http://www.noborder.org/archive/www.deportationclass.com, (accessed 16/09/2016).

${ }^{39}$ G. Heck, 'Illegale Einwanderung'.

16 
40 Bundesverfassungsschutz, Verfassungsschutzbericht 1998, Bundesministerium des Innern, available from http://www.bmi.bund.de/cae/servlet/contentblob/150364/publicationFile/14854/Verfassungsschutzbericht 1998 Id 7295 de.pdf, (accessed 14 September 2016), p. 106.

${ }^{41}$ S. Crage, 'The More Things Change...Developments in German Practices Towards AsylumSeekers and Recognised Refugees', 'German Politics', Vol 25/3 (2016), pp. 344-365.

${ }^{42}$ De'fence Bündnis, 'Flüchtlinge ohne Recht auf Asyl. Aufruf zur Demonstration am 5.7.2008 in Berlin: Für ein globales Recht aufMigration', 5 July 2008, available from: www.friedenskooperative.de/ff/ff08/3-76.htm, (accessed 15 March 2016).

${ }^{43}$ F. John; E. Panagiotidis; V. Tsianos, 'Die Angst vor demElfmeter. Vom Versuch eineandere Ges ells chaft zu realis ieren', European Institute for Progressive Cultural Policies, July 2007, available from http:/eipcp.net/transversal/0707/preclab/de, (accessed 15/09/ 2016).

${ }^{44}$ Antira Hamburg, 'Demonstration Lampedusa in Hamburg am 01.03', Sprachraum HH, 19 February 2014, available from http://sprachraum-hamburg.antira.info/2014/02/19/demonstration-lampedusa-in-hamburg-am-01-03, (accessed 17/09/2016).

45 I. David, 'Demo in der Innenstadt', HH Mittendrin, 31 January 2015, available from http://hhmittendrin.de/2015/01/demo-in-der-innenstadt-es-geht-um-menschen-nicht-um-papiere, (accessed 17/09/2016).

${ }^{46}$ s ee Die Karawane München, 'Statt rassis tischer Hetze und geis tiger Brandstiftung - Einfach mal die Fres se halten', 15 January 2016, available from http://karawane-muenchen.org, (accessed 17/09/2016).

${ }^{47}$ see also J. G. Gerber, Verkehrungen, Die radikale deutsche Linke im Zuge der welt-und deutschlandpolitischen Ereignisse des Jahres 1989, PhD thesis Martin-Luther-Universität, Halle, 2009; Peter Ullrich, Die Linke, Israel und Palästina: Nahostdiskurse in Großbritannien und Deutschland (Berlin: Dietz Verlag, 2008); Gerhard Hanloser (ed.) Sie waren die Antideutschesten der deutschen Linken. Zu Geschichte, Kritik und Zukunft antideutscher Politik (Münster: Unrast, 2004); Anne Joly, „Nie wieder Deutschland“: Nations- und Selbstverständnis in der deutschen radikalen Linken seit 1990, $\mathrm{PhD}$ thes is Paris X Nanterre/HumboldtUniversität 2012a, available from http://edoc.hu-berlin.de/dissertationen/joly-anne-2012-01-28/PDF/joly.pdf, (accessed 13/08/2016) ; C. Koschmieder, 'Die Entstehung der „Antideutschen“ und die Spaltung der links radikalen Szene', in U. Dovermann (ed.), Linksextremismus in der Bundesrepublik Deutschland (Bonn: Bundeszentrale für politische Bildung, 2012).

${ }^{48}$ A. Joly, 'Das antideutsche Phänomen: Eine Eigenheit der deutschen radikalen Linken ', Linksunten, 11 September 2012b, available fromhttps://linksunten.indymedia.org/en/node/66911, (acces sed 28/07/2016); J.G. Gerber, 'Verkehrungen'; also A. Joly, 2012a 'Nie wieder Deutschland', p. 233.

49 e.g. M. Schneider, 'Die Antideutschen und die Radikale Linke', Incipitio 17/2005, available from http://www.leftaction.de/incipito/rechts.php?artikel=353, (accessed 13/09/2016).

${ }^{50}$ A. Joly, 'Das antideutsche Phänomen'.

${ }^{51}$ I. Erdem, 'Anti-deutsche Linke oder anti-linke Deutsche? Eine sachliche Betrachtung', UTOPIE kreativ H. 192 , October 2006, available from https://www.rosalux.de/fileadmin/rls uploads/pdfs/Utopie kreativ/192/192Erdem.pdf,_(accessed 15 March 2016).

52 Robert Kurz, Die Antideutsche Ideologie. Vom Antifaschismus zum Krisenimperialismus: Kritik des neuesten linksdeutschen Sektenwesens in seinen theoretischen Propheten (Münster: Unrast, 2003).

${ }^{53}$ J.G. Gerber, 'In einem Land vor uns erer Zeit. Die linken Antirassisten wünschen sich den Zustand zurück, vor dem sie warnen', Bahamas 66 (2014), p. 23.

${ }^{54}$ Ibid, p. 22.

${ }^{55}$ Ibid, p. 23.

56 T. Kunstreich, 'Willkommensmob und Lynchkultur eint Strafbedürfnis und Geständniszwang. Zwei tote Flüchtlingskinder geben das gute Gefühl eines schlechten Gewissens ‘, Bahamas 72 (2015/16), p. 14.

${ }^{57}$ U. Krug, 'Refugee Revolution? Die Flüchtlingsproteste, der Antirassis mus und die verrohte Ges ellschaft', Bahamas 66 (2014), p. 24.

58 J. Wertmüller, 'Verständnis, Toleranz und Respekt. Antirassisten und Islamisten gemeinsam gegen rechte Verbindungen', Bahamas 46 (2005), p. 5.

${ }^{59}$ T. Kunstreich, 'Willkommensmob und Lynchkultur eint Strafbedürfnis und Geständniszwang, p. 14.

${ }^{60}$ J. Wertmüller, 'Verständnis, Toleranzund Respekt, p. 5' also I. Lehmann, 'Reine Lehre, harter Griff. PoMo Kanaksters gegen Integration', Bahamas 26(2005), p. 45.; Redaktion Bahamas, 'Editorial', p. 5.

${ }^{61}$ J. Wertmüller, 'Verständnis, Toleranzund Respekt, p. 7.

${ }^{62}$ I. Lehmann, 'Reine Lehre, harter Griff. PoMo Kanaks ters gegen Integration', p. 48.

${ }^{63}$ Redaktion Bahamas, 'Editorial', Bahamas 70(2015), p. 4.

${ }^{64} \mathrm{~J}$. Wertmüller, 'Verständnis, Toleranzund Respekt', p. 6.

${ }^{65}$ J. Wertmüller, 'Der deutsche Anschlag auf die Souveränität. Ein Plädoyer für misepetregien Defätismus in der Flüchtlingsdebatte', Bahamas 72 2015/16, p. 31.

${ }^{66}$ I. Lehmann, 'Reine Lehre, harter Griff. PoMo Kanaksters gegen Integration', p. 48.

${ }^{67}$ Teun A. van Dijk, 'Principles of critical discourse analysis', in Discourse \& Society, Vol. 4(2) (1993), pp. 249-283, p. 249. 